\title{
Reassembling the Political: The PKK and the project of Radical Democracy
}

Ahmet Hamdi Akkaya and Joost Jongerden

\section{(2) OpenEdition \\ Journals}

Electronic version

URL: http://journals.openedition.org/ejts/4615

DOI: $10.4000 /$ ejts.4615

ISSN: $1773-0546$

Publisher

EJTS

Electronic reference

Ahmet Hamdi Akkaya and Joost Jongerden, « Reassembling the Political: The PKK and the project of Radical Democracy », European Journal of Turkish Studies [Online], 14 | 2012, Online since 18 January 2013, connection on 16 February 2020. URL : http://journals.openedition.org/ejts/4615 ; DOI : $10.4000 /$ ejts.4615

This text was automatically generated on 16 February 2020.

(C) Some rights reserved / Creative Commons license 


\section{Reassembling the Political: The PKK and the project of Radical Democracy}

Ahmet Hamdi Akkaya and Joost Jongerden

\section{Introduction}

1 One of the most important secular political movements in the Middle East, the Kurdistan Workers Party (PKK) underwent a profound transformation in the 2000s, following the capture of its leader Abdullah Öcalan in 1999. After a long period of a 'national liberation struggle' aimed at establishing its own state, the PKK changed its course towards a project of radical democracy, based on the rejection of the state (Akkaya and Jongerden 2011). The PKK, which had taken its orientation from the revolutionary left in Turkey, was providing a new basis for radical politics in today's Turkey. In this article we will argue that the PKK reinvented itself ideologically through this transformation, and gave shape to new forms of politics on the basis of an exploration of the concept of democracy. In this article we explore the content of this new project, and its practical implications. We will not discuss the organizational restructuring related to the PKK's new political project, since we have discussed this elsewhere (ibid.).

2 Through this discussion, our study addresses a gap in Turkish and Kurdish studies. Although the Kurdish question in Turkey has been studied considerably, the focus has been on state discourse and security policy, with little attention devoted to the role of the Kurdish agency itself, and in particular the PKK (Barkey and Fuller 1998; Yegen 1999; Heper 2007). Only few studies deal explicitly with the political ideology of the PKK. ${ }^{1}$ Furthermore, works on the PKK tend to treat the PKK as an anomaly, rather than making sense of it. In this article, we study the PKK's political project as developed in the first decade of the new millennium and try to understand how the PKK itself makes sense of this project. In doing so, the present piece promises both to advance 
knowledge related to our understanding of political life in contemporary Turkey, and to make a critical contribution to contemporary discussions related to radical democracy.

3 The data for this article has been collected through a study of Öcalan's defence texts and his 'prison notes', along with key PKK documents, such as congress reports, formal decisions and the writings of its cadre, such as Mustafa Karasu. The article is composed of four parts. First, we trace the evolution of radical democracy as an important concept in political philosophy on the basis of its foundations and the subjectivities which shape it. Then, we take a closer look at the changes the PKK underwent after the arrest of Öcalan, mainly considering its ideology. What the PKK refers to as "radical democracy" will be elaborated on in this part, with the political projects developed within the context of radical democracy - democratic republic, democratic confederalism and democratic autonomy - discussed in detail, with consideration given to theoretical implications. Third, the political dimension of these projects will be studied in answer to the question of how they currently determining PKK strategy and day-to-day activities. Finally, in the fourth part, this project of radical democracy and its political implications will be discussed in terms of the contingencies they create in finding a solution to the ongoing conflict in Turkey.

\section{Radical Democracy as alternative to Liberal Democracy}

4 Since the late 1970s, the understanding of radical politics within the framework of Marxism has changed.This change focused on its approach to three important pillars of politics; state, class and party, and radical political thought took the form of 'politics beyond the state, political organisation beyond the party, and political subjectivity beyond class' (Badiou 2002: 95-97). ${ }^{2}$ Within this understanding of radical politics, the reformulation of 'radical democracy' has emerged as the main alternative to liberal democracies of the West. It has given a fresh impetus to the social and political movements, from 'liberation movements' in Latin America to anti-globalist demonstrations in the US and Europe. In this sense we can talk about a wide spectrum of radical views of democracy beyond the liberal version. In critical academia the most well-known was the reconsideration of the concept of democracy in Ernesto Laclau and Chantal Mouffe's pioneering study Hegemony and Socialist Strategy: Towards a Radical Democratic Politics, first published in 1985. Laclau and Mouffe had sought to spell out a left-wing alternative of radicalising democracy, deepening it in the light of ever present conflicts and power. ${ }^{3}$

5 In the context of this article, however, our focus will mainly be on the studies by Michael Hardt and Antonio Negri $(2004,2009)$, which provided a new momentum to the discussion concerning radical democracy because of their emphasis on the importance of political struggle. ${ }^{4}$ Hardt and Negri's tripartite structure moves from an analysis of the sovereignty in the age of globalisation - form what they call 'Empire' (2000), 'the living alternative that grows within the Empire,' through 'Multitude' (2004), an 'institutional structure and ... [the] political constitution of society' - to what they call 'Common Wealth' (2009)..This scheme can be summarised as an analysis of sovereignty in the globalised world (Empire), of the revolutionary subject of the period (Multitude) and of its political project of 'expanding our capacities for collective production and 
self-governance' (Commonwealth) (2009: xiii). It is this latter sense of radical democracy as developed by Hardt and Negri that is more meaningful to the Kurdish project, especially how they conceive representation and sovereignty.

Hardt and Negri aimed to work out the conceptual basis for a new project of democracy. For them, democracy has remained an incomplete project throughout the modern era, and they try to revitalize its liberating content as constituted in the idea of popular sovereignty (the word sovereignty derived from the Latin supremitas or suprema potestas, meaning 'supreme power'), which may be defined as a power that belongs to the people with no power above it. They identify several debates related to the idea of democracy today, but for us the most important are the debates on the subversive characters of democracy and of representation.

7 The subversive character of democracy is related to the fact democracy has been an incomplete project. Hardt and Negri argue that it was only through social struggle that democracy started to include the excluded, such as "women, the propertyless and the non-white." In a similar fashion, democracy came to be discussed in the domain of economy, which in liberal theory is not governed by democracy, but markets. This extension of democracy can be referred to as the 'subversive character of democracy': it allows its extension to all facets of society.

8 The second is related to (political) representation, or the separation of sovereign power from society that is embedded in the concept of representation: "When power is transferred to a group of rulers, than we all no longer rule, we are separated from power and government" (Hardt and Negri 2004: 244). Since the $18^{\text {th }}$ century, this conception of representation had come to monopolize the field of political thought to such an extent that any contemporary project of democracy has to begin with a critique of the existing forms of representation.

9 To this end, Hardt and Negri, following Max Weber, discuss the different forms of representation that have appeared throughout history. ${ }^{5}$ Referring to the socialist political representation, based mostly on the experience of 1871 Paris Commune, Hardt and Negri state that this failed in a way similar to the liberal and constitutional model. Thus they set about a search for new forms of representation that limit the separation between the representative and the represented, and in so doing, simultaneously create alternatives for the state based on the separation of sovereign power from society (Hardt and Negri 2004: 245-6; 250-1). In this sense, they claim that the Multitude as the 'revolutionary subject' of the period and its political project (Commonwealth) can present new contingencies for inventing "different forms of representation or new forms of democracy that go beyond representation" (2004: 255). Constitutive of this new concept of democracy the Multitude is conceptually distinguished from other notions, such as 'the people', 'the masses', and 'the working class', and it can never be reduced to a unity or a single identity. Rather "in conceptual terms, the multitude replaces the contradictory couple identity-difference with the complementary couple commonality-singularity" (2004: 218) and it is "the adequate subject which can construct a new community" (Çıdam 2010). ${ }^{6}$

10 In this line of discussion, Hardt and Negri elaborate on how in different struggles, the rebellions of different singularities can be brought together as a form of revolutionary assemblages, beyond the hegemonic articulation posed by Laclau and Mouffe. They discuss "the parallel coordination among the revolutionary struggles of singularities" (Hardt and Negri 2004: 344). However these parallel struggles of identities or 
singularities are not sufficient for a revolutionary change: there needs to be radical change in the forms of the organization and decision-making processes.In this sense, the political organization of the Multitude should also be substantially different from that of previous resistances, with democracy as not only an aim to be achieved but also a fundamental principle according to which the whole organizational structure is governed. This democratic political organizational form will add another element to the destabilizing and destructive activities of previous revolutionary activities which were led by vanguard organizations; the project of constructing a new type of power. In this new type of power, by which the multitude is capable of managing the common, there is no place for taking control of the state apparatuses. Rather the multitude's capacities for democratic decision-making should be consolidated: "Making the multitude is thus the project of democratic organising aimed at democracy" (2009: 363). For Hardt and Negri, this making the Multitude based on "the revolutionary assemblages of different singularities" has the capacity to change the existing patterns of both representation and also sovereignty. The existing concept of sovereignty is based on one basic principle: 'rule by 'the one', whether this be the monarch, state, nation, people, or party' (2004: 328). In this conception of sovereignty, the people, the nation, united in a single body, plays the role of 'unitary political subject'. In the democracy of the Multitude, however, there is no place for such sovereignty, and the consequent challenge to all existing forms of sovereignty is at the same time a precondition of that democracy.

In all these discussions, Hardt and Negri admit that this revolutionary process is not spontaneous and must be governed - but certainly by new forms and tools:

This would have to be democratic not in the false sense that we are fed every day by politicians and the media with their pretenses of representation, but in the active and autonomous self-rule of the multitude as a whole. (2009: 372)

Only through this form of self-rule can the dilemmas of vanguards, leadership and representation that plagued previous revolutions be overcome.

In this respect, and contrary to contemporary standpoints on the right as well as on the left, Hardt and Negri give importance to identity politics:

Here is the conundrum we face: revolutionary politics has to start from identity but cannot end there. The point is not to pose a division between identity politics and revolutionary politics but, on the contrary, to follow the parallel revolutionary streams of thought and practice within identity politics, which all, perhaps paradoxically, aim toward an abolition of identity. Revolutionary thought, in other words, should not shun identity politics but instead must work through it and learn from it. (2009: 326)

Hardt and Negri define three important tasks in this working through identity politics. The first is to make visible the subordinations of identity which means reappropriating the identity; the second is to rebel against the structures of domination using the subordinated identity as a weapon in the quest for freedom; and the third is to strive for its own abolition (2009: 327-333). They see these three tasks as inseparable and to be "pursued simultaneously, without, for instance, deferring the revolutionary moment to some indefinite future" (ibid.: 337).

From here, we may indicate links to the PKK's project for radical democracy, which has envisaged these three different tasks of identity politics. In this project, and just as in Hardt/Negri's conceptualization of radical democracy the concept of struggle plays a very crucial role - indeed, it is through struggle that subjectivity is created. Similar to 
Hardt and Negri, the PKK returns to an early modern conception of democracy, with Öcalan arguing that one of the promising elements of early socialist traditions was the idea of constructing democracy from below and the rediscovery of the idea of the multitude, including different subject positions. ${ }^{7}$ The development of the Kurdish issue as a field of struggle for freedom and equality is an illustration of the various contradictions and the plurality of the social. At the same time, the history of the Kurdish issue in Turkey shows us the difficulties the left had in articulating this struggle through socialist strategies. The traditional left demanded the organization of struggle around class, and in doing so, brushed aside the series of contradictions emerging in and from the Kurdish issue (such as those of de-colonization, and language, cultural and civil rights).

The PKK, which can be criticized for the lack of democracy in its own ranks, is at the same time developing a program of radical democracy. This may be referred to as a 'Jacobin paradox'. It was the Jacobins, responsible for the reign of terror, who developed democracy as a political project (Žižek 2007). The PKK is Jacobin in the sense that it simultaneously uses violence as an instrument for the realization of its political program of radical democracy.

\section{Radical Democracy in Kurdish Context}

During the 2000s, the PKK elaborated a new ideological framework promoting this project of radical democracy. In doing this, the PKK made a kind of 'salto mortale' by reinventing itself through a series of transformations and arguing that the nation be defined not on the basis of ethnicity or language but on the basis of citizenship in a democratic republic. ${ }^{8}$

The PKK's ideological transformation towards a project of radical democracy was based on the defence texts written by Öcalan and submitted to the different courts in which he his case was heard. These defences can be grouped into two: those submitted to the Turkish courts, and those submitted to the European Court of Human Rights (ECHR) in Strasbourg, France, along with one at a court in Athens (concerning his expulsion from Greece). The defences have been published in Kurdish and Turkish as well as in other languages. ${ }^{9}$ These defence texts were accepted in the consecutive PKK congresses as the official party line. Initially the texts led to serious confusion in the movement, but since 2005 the ideological and organizational structures have been adapted to one another.

The first texts, submitted for the case in Imralı and then to the Court of Appeal in Ankara, caused considerable unrest among PKK militants, since Öcalan did not take the assumed position expected by the party and the Kurdish population. On the contrary, he rejected claims for an independent state - previously a central aim of the struggle proposing a new, 'truly' democratic republic.In these texts Öcalan did not engage with theoretical or ideological considerations; they were mainly based on the historical background of the Turkish-Kurdish conflict in the twentieth century, in which Öcalan stated that he had struggled in favour of a democratic republic, and thus not against the Republic (of Turkey). Öcalan argued that Mustafa Kemal, the Republic's founding father, had also intended to establish a democratic republic, but was confined by external forces. Of Öcalan's defences, only this first one can be considered as a genuine defence to his prosecution, although he argued that he was not concerned with the legal issue of his case. 
21 In his second group of defence texts, submitted to the ECHR, Öcalan deepened his theoretical considerations. The first of the three volumes dealt mainly with a historical analysis of civilization, starting in the Middle East, and focusing upon the Sumerians as 'the earliest state-based' society. Although Öcalan elaborated in later parts of the book on other societies and periods, his main concern was to present the state as the 'Original Sin' of humanity. This was surprising as he was, and is still, one of the political leaders of a society which has been widely depicted as 'the largest people in the world without a state'. Initially it created a kind of alienation among Kurdish circles (a Verfremdungseffekt, in the Brechtian sense). However, Öcalan continued to elaborate on his critique of the state, including the socialist experiments, arguing that liberation cannot be achieved by means of state-building, but rather through the deepening of democracy. In the second volume of his ECHR defence texts, Öcalan dealt intensively with Kurdish society, history and specifically the role of the PKK. He places Kurdish society in the history of civilization, presenting it as a natural society or community opposed to state-societies. The Kurdish society's naturalness is attributed to an assumed long standing and deep Neolithic culture among the Kurdish tribes. ${ }^{10}$ For Öcalan, class (state) societies and modernization have caused destruction for the Kurds, and the PKK has become the locus of the last resistance to this pernicious process. Within this framework, Öcalan tried to show the limits of the PKK and its deadlock, trapped in the ideological-political constraints of the Cold War, which was continuing to condition the PKK, even a decade after it ended. Through this work, he aimed to evaluate the history of the PKK, addressing past mistakes.

In these defence texts, submitted to an Athens court and the ECHR Grand Chamber, Öcalan transformed his theoretical considerations into a concept of radical democracy. This idea of radical democracy was developed in three intertwined projects: democratic republic, democratic autonomy and democratic confederalism. These three political projects function as a 'strategic dispositif': ideas and means through which Kurdish political demands are (re)defined and (re)organized.

23 The concept of the democratic republic comprehends a reform of the Republic of Turkey. It aims at the disassociation of democracy from nationalism, and as such a return to the "early modern conceptions of democracy" and their radical subversivity (Hardt and Negri 2004: 240-251). Originally, in the eighteenth century, democracy was formulated in terms of citizen's rights and a rule of everyone by everyone. In the course of the nineteenth and twentieth century however, modernity lost its content of radical democracy and acquired a cultural meaning, referring to a unique people (Jongerden 2007: 7-8). A vein in modern thought emerged which considered cultural homogeneity a requirement for the modern state, an inescapable imperative that manifests and erupts in the form of nationalism (Gellner 1983). This 'national' condition of modernity is exclusive and intolerant, dictating that people who do not have the 'right' cultural characteristics are to choose between assimilation (genuine or superficial) and migration, while the options of the state range from assimilation to eviction and ethnic cleansing, or genocide (Gellner 1997: 240). In Turkey, Kemalism was formulated as a project of modernization in cultural terms, resulting in harsh assimilation politics towards the Kurds. With his proposal for a democratic republic, Öcalan advocates an understanding of democracy in terms of citizens' rights.

Öcalan's radical democracy of his later defence texts was embodied in the concept of democratic confederalism which he borrowed from the works of Murray Bookchin 
(1982, 1992, 1993,1996). Bookchin, who called his ideology communalism, suggests a new radical politics recognizing 'the roots of democracy in tribal and village communities' (White 2008: 166) and ends up with a project of Libertarian municipalism. In this project, he aims at creating local democratic structures such as 'community assemblies, town meetings and neighbourhood councils'. Avoiding the project of libertarian municipalism from becoming vacuous or being used for highly parochial ends, Bookchin suggests the principle confederalism as 'a network of administrative councils whose members or delegates are elected from popular face-to-face democratic assemblies, in the various villages, towns, and even neighbourhoods of large cities' (Bookchin 1993). For Bookchin, confederalism as a principle of social organization 'is a way of democratizing the interdependence without surrendering to the principle local control'.

Öcalan, influenced by the ideas of Bookchin, developed a similar understanding of that principle of confederalism. In parallel to his historical analysis of civilization based on the critique of the state, Öcalan condemned the failure of real socialism and national liberation movements who were considered trapped in the ideas of the state and statemaking. Alternatively he elaborated on the protracted effects of the Neolithic society whose communal values could not have been completely destroyed by the development of hierarchic society built upon the state. Those communal values which were summarized as the socialization based on gender, life compatible with nature and society based on communality and solidarity underlie his conception of democracy in the form of democratic confederalism. On the basis of those values, the project of democratic confederalism is organized at four levels (Karasu 2009: 84-85). At the bottom, the communes in the village and districts which are interrelated at the levels of towns, cities and regions, are situated. Then the organization of the social groups such as the women, youth etc. exists. Another level of organization occurs at the cultural scale in terms of organization for different ethnic-religious-cultural identities. The fourth and final level is the level of civil society organizations. In this sense the democratic confederalism, based on a kind of assemblies at village-districts, city and region levels, refers to organisation of the whole society starting from the bottom-up (ibid.: 80). In another saying, the idea of democratic confederalism was defined as a model for 'democratic self-government'. "This project", Öcalan argues, "builds on the self-government of local communities and is organized in the form of open councils, town councils, local parliaments and larger congresses. The citizens themselves are agents of this kind of self-government, not state-based authorities" (Öcalan 2008: 32).

In this sense Öcalan has continuously emphasized that this project has nothing to do with a confederal structure as 'an association of sovereign member states'. On the contrary, democratic confederalism aims to consolidate and deepen democracy at the grassroots on the basis of communities. However there is also the need to reclaim the juridical and political procedure, to reshape the political organization of a country. Therefore the model of organizing the people beyond the state should define its relationship with the existing state or official authority. For this Öcalan first proposed the democratic republic as the form of government through which the Kurdish question can be solved, and then he developed the concept of democratic autonomy as a form of relationship. In this sense, democratic autonomy refers to the type of relationship with the state and in turn with its jurisdiction. In the Turkish context, it was presented as the option for a democratic political solution to the Kurdish question, requiring constitutional recognition of the Kurdish national identity. However this 
recognition was not proposed by the PKK as a way to draw a line between the Kurds' democratic confederal system and the Turkish state. Rather a nested relationship is anticipated which is stated in such way that "Democratic autonomy is a concept which defines the relationship with the state... It can be (realized) even within a unitary structure or in a structure of the states" (Karasu 2009: 260 and 275).

However this nested relationship does not exclude a kind of 'unity' among the Kurds dispersed over different countries of the Middle East. Since Öcalan proposes to build self-governing bodies throughout Kurdistan, and wherever there are Kurds living, democratic confederalism is to be considered the main mechanism for the unification of Kurdistan and Kurds. The Kurdish liberation movement, Öcalan argues, should work for the establishment of such a system of self-organization.

Consequentially since 2005, the PKK and all-affiliated organizations have been restructured on the basis of this project under the name of KCK (Association of Communities in Kurdistan -Koma Civakên Kurdistan) which is a societal organization presented as an alternative to the nation-state. The KCK has aimed to organize itself from the bottom to the top in the form of assemblies. "KCK is a movement which struggles for establishing its own democracy, neither ground on the existing nationstates nor see them as the obstacle" (PKK 2005: 175). In its status, called KCK Contract, its main aim is defined as struggling for the expansion of radical democracy which is based upon peoples' democratic organizations and decision-making power. The KCK contract sets forth a new mechanism of social relations which transcends the statist mentality. In this sense, the democratic confederalism as the main organizing idea of the KCK is valid everywhere where the Kurds live, even in Iraq, where Kurds have constitutional rights including self-governing their region in a federal state structure. In this project, there are two determining factors which are the notion of the democracy as people's power based on society, not as a form of government, and secondly the exclusion of the state and nation from this notion.

For Kurdish people, democratic confederalism as a form of political and social system beyond the state is project for its own free life. It has nothing to do with the recognition by the states. Even though the states do not recognize it, the Kurdish people will construct it. If they recognized it, for example within a project of democratic autonomy, it would be easier to construct a democratic confederal system which would be in the end the product of Kurds' own struggle (Karasu 2009: 216-217).

In tracing the development of Öcalan's thought in general, we argued that three intertwined concepts (democratic republic, democratic confederalism and democratic autonomy) played a pivotal role. In all of these projects the concept of democracy has a central importance and it has evolved from a notion based on a contradiction between the democratic and republican tradition to a more radical conception of democracy. For the PKK, democracy represented a kind of antidote to the central character of the Turkish republic, which was, and still is based on the French version of nationhood and secularism. 'The centrality kills democracy' is a very basic idea of this approach (ibid.: 86).

31 Now we will look at how these projects determined the political activities of the PKK and all-affiliated organizations. 


\section{Back to the Stage}

organizations have undergone a series of changes mostly in terms of organizational reconstruction. In this sense, the period between 2000 and 2004 can be considered as a period of 'impasse and reconstruction' during which the PKK had levelled down its demands, ceased military activities, withdrew the majority of its guerrilla forces from Turkey into Northern Iraq and consequently gave an impression of introversion. The political activities of the PKK were confined to Öcalan's case, whose sentencing made Turkish officials to consider the PKK defeated and dissolving. Not unpredictably, the partial success of the pro-Kurdish Demokratik Halk Partisi (DEHAP; the Democratic People's Party,) in the November 2002 election - when it won 6.2 per cent of the popular vote in Turkey, thereby failing to reach the 10 per cent threshold but managing to become the leading party in the Kurdish region - did not change the attitude of the Turkish officials to Öcalan's case, the PKK or the Kurdish problem in general.

Concurrently with the US invasion of Iraq in 2003, which paved the way for recognition of Iraqi Kurdistan as a new centre of attraction among the Kurds, the PKK experienced the greatest split it ever faced. The movement suffered a kind of limbo between 2004 and 2005, struggling to come to terms with the internal and external developments. There was deadlock, created by the difficulties to advance in a period of uncertainty. At the same time, with the local elections of 2004, the pro-Kurdish party DEHAP lost votes compared to 1999. Some of the Kurdish cities were taken by the ruling party, the Adalet ve Kalkınma Partisi (AKP; the Justice and Development Party), which swept to power in a wave of national populism.

Öcalan and the PKK tried to overcome this crisis through an organizational restructuring within the framework of the idea of democratic confederalism. Among the organizational steps taken in this period, the restructuration of all PKK-affiliated organizations under the umbrella of KCK and the establishment of a new pro-Kurdish party, the Demokratik Toplum Partisi (DTP; the Democratic Society Party) in Turkey were the most striking ones. On this basis, the movement has returned to the stage of political and later also military confrontations since 2005. The Kurdish movement confronted the Turkish state with civil campaigns openly demonstrating Kurdish identity claims. In this regard, the campaign for the right of education in the mother language (Kurdish) and the campaign for Öcalan in which more than three million Kurds in Turkey and Europe signed up to a petition stating that they 'recognize Öcalan as their political representative', have been the most powerful signals of future Kurdish identity politics.

With the election of 22 DTP deputies in the July 2007 national elections, Kurdish politics became integral to Turkey's political agenda. Later on, in south-eastern Turkey, the next election campaign (conducted nationwide for the municipalities in March 2009) turned into a political contest between the AKP and DTP, with the DTP gaining the upper hand. The DTP won the local elections of March 2009 and nearly doubled the number of municipalities under its control - to almost 100 Kurdish cities and towns, including Diyarbakır and seven other important cities (Casier, Jongerden and Walker 2011). It has been argued that, the DTP should be taken as interlocutor, and "with its incontestable success in the southeast at least should be accepted as the main player in 
the region" (Birand 2009; Ergin 2009). Some newspaper columnists even considered the PKK and Öcalan as among the actors in a possible dialogue, suggestions rarely read in mainstream Turkish press (Ozkök 2009; Akinan 2009). Thus, it would appear that the PKK not only reinvented itself, but also returned to the forefront of politics in Turkey.

But more importantly, during this period, Kurdish politics gained supremacy in appropriating the space which refers to "the potential of social movements to alter power structures in a given polity" (Gambetti 2009: 44). This appropriated Kurdish public space, mainly symbolized in Diyarbakir, was, maybe for the first time, combined with nationwide Kurdish politics, including the Turkish parliament in Ankara which "marked the opening of differential political and social spaces within the territory of the nation-state" (ibid.). In this sense, the municipalities under the control of proKurdish party since 1999 have formed a kind of self-ruling regional body. Gambetti calls this on the basis of Diyarbakır's case as "engaging in the city's decolonization".

Again during this period, the DTP started to voice more openly its political project, the 'Project for Democratic Autonomy', very much in accordance with Öcalan's concept of democratic confederalism. For this purpose, 'Democratic Society Congress' was held in Diyarbakir in October 2007 which recognized 'democratic autonomy' as a project for Kurdish people in Turkey. This congress report called for radical reforms in Turkey's political and administrative structure in order to ensure democratisation and to develop problem-solving approaches for which the local level should be strengthened. Instead of autonomy based on 'ethnicity' or 'territory', it suggested regional and local structures which allow for the expression of cultural differences.

In this regard it proposed the foundation of 26 parliaments covering all regions of Turkey. The report also called to change the definition of 'nation', with its ethnic emphasis, to 'The nation of Turkey', in order to find a shared sense of belonging. ${ }^{11}$ Later on, in November 2007, the DTP held its second congress in which this report was recognized officially by the name of 'Democratic Solution to the Kurdish Question Democratic Autonomy Project'. This very important development concerning the Kurdish politics in Turkey showed explicitly the Kurds' ascending identity demands. This was also interpreted as a new era in the legal Kurdish politics in which the DTP came to play an important role for the policy of solution whereas the former legal Kurdish parties, HEP, DEP, HADEP and DEHAP all of which banned by the Constitution Court, were confined to a struggle for existence against the policies of denial and annihilation. ${ }^{12}$

In the same congress the DTP adopted some important changes in party statutes in accordance to the concept of democratic autonomy aiming at the formation of assemblies at each level of organization. Similarly the municipalities under the control of the DTP took some steps towards the Kurdish identity politics amongst which the 'multilingual municipality service' sparked a heated debate. In 2007, mayor of the Sur municipality in Diyarbakir, Abdullah Demirbas offered municipal services not only in Turkish, but also in Kurdish, Armenian and Syriac (Casier 2010). Because of this multilingual project, the mayor was taken from office and his municipal council was dissolved. He was also charged with 'harming the public by abusing their position' and 'acting in contradiction with the Turkish letters'. However in the local elections of 2009, Demirbaş was re-elected mayor with more votes than before. ${ }^{13}$

40 Apart from the legal party organization, ${ }^{14}$ the new Kurdish project set forth another form of organization, named the Demokratik Toplum Kongresi (DTK; Democratic Society Congress),${ }^{15}$ which has been founded on basis of the following argument: 
41 Today we had some district and town councils, even if they are local and inadequate. Since they are not well-founded, the Kurdish people bring their demands to the political party and reflect them through it to the state. But according to our project, the state should keep its relationship with the Kurdish people through this congress. If the Kurdish people assembled under the same roof of this Congress, they would be interlocutor for a solution. And the state which came to an agreement with this body relinquishes its old structure. ${ }^{16}$

This approach is based on Öcalan's view of 'democracy without the state' in which he argues for a compromise on a small state with limited power. For him, the Kurdish people should have their own democratic power structure in their region and this 'democracy + Turkish state as a general public authority' is a fundamental formula for a solution (Öcalan 2004: 402).

The DTK was formed on this basis so as to forge a new political style, defined by the direct and continual exercise of people's power and since then it has been concerned with the various forms of societal organizations, including the district-village, town and city councils, women and youth associations, and the non-governmental organizations. The spokesmen of the councils and the delegates elected at the district levels comprise $60 \%$ of the congress whereas $40 \%$ are representatives of NGOs. The DTP is also one of the constituents which represent the political space. 600 delegates attended the first (foundational) meeting of the Congress in October 2007 in which the project for Democratic Autonomy was announced. The second meeting was held in September 2008 and it took a stand against the ground and air operation of the Turkish Army into Northern Iraq. A third meeting held in 2009 just before the nationwide local elections discussed the election strategy. The DTK held a fourth and fifth meeting in June and December 2009 in which it proposed a new constitution, involving an autonomous Kurdistan. ${ }^{17}$

Alongside these organizational activities, the DTK organised an international symposium and various workshops on 'New Economic Policies', 'Religious Belief Groups', 'New Constitution' and 'on Language'. A 'Conference on Experiences with Negotiation and Conflict Resolution' was held discussing how to create dialogue between parties in order to share experiences and ideas about peace processes, road maps and other related subjects. ${ }^{18}$ In its final declaration, a solution of the Kurdish question through dialogue was proposed. The international community was called to make a contribution to the dialogue process. In this respect, the necessity for both Turkish and Kurdish parties to confront the past was also emphasized. ${ }^{19}$

In the workshops the DTK presented autonomous local governments, ${ }^{20}$ education in the mother tongue and recognition of the identity as common demands of the Kurdish people. The workshop on language, organized in collaboration with some nongovernmental organizations in June 2010, suggested a project for the protection of languages which are not (official) languages of instruction. It was recommended that Kurdish and other languages should be the language of instruction. In this regard the workshop emphasized that non-state actors should not confine themselves to raise demands for official recognition of the Kurdish language but should also organize it by themselves. ${ }^{21}$

46 In sum, we may conclude that since 2005, Kurdish movement in Turkey within the framework of democratic confederalism, gradually opened up a political and social space for the Kurdish identity. While going through such a process, the Kurdish 
movement, which has governed a significant number of municipalities since 1999, has been based on two main organizational forms, the legal party, the DTP and afterwards the BDP and a wider congress, the DTK. They aimed at expanding the Kurdish identity politics based on the concept of democratic confederalism and democratic autonomy. Lastly, the DTK proclaimed that it will construct 'Democratic Autonomy' from the bottom-up. Though admittedly vague in its content, this proclamation constitutes, on the one hand, the boldest effort ever made by the Kurdish movement to forge a disengagement from the Turkish public sphere which brings with it an increased risk of clashes. On the other hand, it can pose the question, could this be the framework of a 'real' solution? In the last part of the article we will discuss this in relation to the possibilities of a political solution for the Kurdish issue.

\section{Conclusion}

To conclude we will discuss the contingencies of this project of radical democracy and its political implications for a solution to on-going conflict in Turkey. First we discuss what this project has meant for the Kurdish movement in Turkey.

It is clear that the 2000s has been the most critical period yet for the PKK. The party has experienced this critical period in different phases, which can roughly be divided into three stages: a) shock and retreat (1999), b) impasse and reconstruction (2000-2004) and c) return to the stage (2005-today). Kurdish and leftist criticisms of Öcalan's new policies and the PKK during this period have ranged from accusations of surrender to the Turkish state, even with allegations of being in the service of the Turkish General Staff, to charges of a complete break with the movement's past and its aims, with the conclusion that they are saying farewell to the dream of an independent united state.

What the PKK has experienced in this period was a comprehensive restructuration of its organization, ideology and political-military struggle. Organizationally the PKK has grown into a complex system of parties and institutions, as opposed to the Leninist style of a pioneering party directly overseeing all its activities, as it previously did. Although there have been considerable changes in the organizational structure, the devoted militant body that is constituted by a group of 'professional full-time revolutionaries' continues to occupy the central role. The change at the organizational level towards a more complex organizational structure - or, towards a multiplicity of interacting institutions - is a reflection of this evolving praxis. This transformation of the organizational structure addresses a new conception which is 'political organization beyond the party'.

Though it has been argued that the PKK abandoned its original position, the realization of an independent Kurdistan, we may argue that the party creatively inversed the original Leninist thesis. In 1914, Lenin argued that "it would be wrong to interpret the right to self-determination as meaning anything but the right to existence as a separate state" (Lenin 1914). Inversing this thesis, one could say it is equally wrong to interpret the right to self-determination as having no other meaning but the right to exist as a separate state. According to Mustafa Karasu, a leading PKK veteran, socialists should not fixate so much on the state as its political project. The concept of the nation-state, he argues, is not a socialist, but a bourgeois concept. The PKK's project of 'radical democracy', and more in particular the idea of democratic-confederalism, developing a bottom-up democratic system beyond existing borders, aims to render borders flexible, 
and in the long term irrelevant (Karasu 2009: 17-219). As a matter of fact, through its political projects of democratic-republic, democratic-autonomy and democraticconfederalism, the PKK is drawing a new agenda for self-determination, while simultaneously going beyond the concept of the nation-state.

More importantly, during this period the PKK managed to assemble Kurdish identity demands into a project of radical democracy.This has been achieved through the elaboration of new ideological and political approaches, which created opportunities for the PKK to enlarge its scope of interest and activities, thereby creating more space for a Kurdish public sphere. In aiming at the transformation of society in all aspects rather than capturing state power through armed struggle, PKK efforts now allow for a broader field of operation.

The political-military struggle, meanwhile, shifted more and more in the direction of a political struggle in which the DTP (afterwards the BDP) with its grassroots organization and elected representatives (nationally and locally) and the DTK have started to take the lead. Especially after the elections of 2007, 2009, and 2011 a more powerful Kurdish public sphere emerged. A prominent Turkish columnist wrote as early as 2004:

After the painful period which Turkey experienced in the last quarter of the twentieth century, a separate state could not be established on its soil, but a separate political geography has been formed in its Southeast. (Bila 2004: 10)

He could not be more right, but maybe did not foresee its concrete manifestation. This separate political geography is based on forms of self-organization (democratic confederalism) and the strong conviction and praxis to take one's own fate in one's own hand. Since the election in 2009 this 'separate political geography' has been deepened with the arrest of Kurdish politicians, followed by a political countercampaign of the Kurdish movement, including demands for bi-lingual public life within the framework of the project for democratic autonomy. The Peace and Democracy Party (BDP) and the Democratic Society Congress sparked the discussions on a "Bilingual Life" by demanding the official recognition of Kurdish language in public life. They also started to put their demands into practice, with municipalities changing the signboards of the municipalities to Kurdish and Turkish, and local shop keepers changing their sign boards into Kurdish. The organization the whole society from the bottom has been on the agenda of the Kurdish movement since 1999, with the takeover of an increasing number of municipalities in the Kurdish region. On the basis of districts and towns, the Kurdish movement has formed different structures of selfgovernment producing policies for the local needs. Later on the project of democratic autonomy aimed at enlarging and formalising these structures..$^{22}$

In the meantime, the Kurdish movement also tried to present and discuss these projects to both the Turkish and the global public opinion, with the organization of the Mesopotamia Social Forum in 2009, ${ }^{23}$ bringing together organizations and movements from the Middle East and several other countries in the city of Diyarbakır, and the DTK organization of a workshop with Turkish journalists, academics, politicians and rights defenders to discuss the project of 'Democratic Autonomy' in 2010. The organization of all segments of society from the bottom-up, under the principle of democratic confederalism and autonomy, has been covering very different fields of social life and required various activities. All these activities show that the PKK's project of radical democracy involves an active agency of people, in the form of a struggling force from 
the local to the regional and global, and more importantly, it shows that it is a project that is based on bottom-up democracy, and cannot be simply considered a political project imposed from above. Through communes and people's assemblies, it aims to surpass the deadlock of representational democracy. In this sense, the democratic autonomy project in the form of 26 autonomous regions as formulated by the Kurdish movement presents a radical alternative which goes beyond the boundaries of the existing political regime. Above all, it is based on a radical conception of democracy aiming at the dissociation of democracy from nationalism by excluding state and nation from it and considering democracy as an unrestricted and unmediated form of people's sovereignty rather than a form of government. Therefore this project for democratic autonomy goes beyond the boundaries of the existing political regime as well the framework elaborated on the basis of EU "acquis communautaire, which uses liberal democracy as its benchmark", although there is an on-going discussion if this proposal might suit the EU Regional Policy given it could be a useful step towards a solution of the Kurdish question by abolishing the centralism in Turkey. ${ }^{24}$

The Kurdish movement is ready to negotiate a solution on the basis of recognition and self-administrative rights. They can negotiate the form and boundaries of this selfadministration but do not abandon it. In this sense, the Kurds want to be included in the political body with their identity based on their inscribed 'political geography' which requires a constitutional recognition of the Kurdish identity in Turkey. This constitutional recognition, including the notion of autonomy, would also mean a radical change in the existing political regime of Turkey..$^{25}$

In sum, the Kurdish movement in Turkey which has developed a new project for radical democracy based on the conception of 'politics beyond the state, political organisation beyond the party, and political subjectivity beyond class' can have the opportunity to change the centralist tradition in Turkish political system as well as the statist and class reductionist political thought in the Left in Turkey.

\section{BIBLIOGRAPHY}

Akinan, S. (2009) ‘Güzel günler yakında mı?’ (accessed 9 April 2009).

Akkaya, Ahmet Hamdi and Joost Jongerden (2011) 'The PKK in 2000s: Continuity through breaks?' In: Marlies Casier \& Joost Jongerden. Nationalisms and Politics in Turkey: Political Islam, Kemalism and the Kurdish Issue. London \& New York: Routledge.

Badiou, Alain (2002) Ethics: asn essay on the understanding of Evil. London - New York: Verso.

Birand, M. A. (2009) 'Let's hear the voice of the Kurds (II)' (accessed 9 April 2009).

Barkey, H. \& Fuller, G. (1998) Turkey's Kurdish Question. Oxford: Rowman \& Littlefield.

Bila, Fikret (2004) Satranç tahtasındaki yeni hamleler: Hangi PKK?, Ankara: Ümit Yayıncılık.

Bookchin, Murray (1982) The ecology of freedom: the emergence and dissolution of hierarchy.

California: Chesshire Books.

European Journal of Turkish Studies, 14 | 2012 
Bookchin, Murray (1992) Libertarian Municipalism: An Overview, Society and Nature, vol.1, No.1.

Bookchin, Murray (1993) The Meaning of Confederalism, Society and Nature, vol.1, No.3.

Bookchin, Murray (1996) From Urbanization to Cities: Toward a New Politics of Citizenship. London: Cassell.

Casier, Marlies (2010) ‘Turkey's Kurds and the Quest for Recognition. Transnational Politics and the EU-Turkey accession negotiations', Ethnicities 10 (1), pp.3-25

Casier, Marlies (2011) 'Beyond Kurdistan? The Mesopotamia Social Forum and the appropriation and re-imagination of Mesopotamia by the Kurdish Movement'. Journal of Balkan and Near Eastern Studies 13 (4), pp.417-432.

Casier, Marlies, Joost Jongerden and Nic Walker (2011) 'Fruitless Attempts? The Kurdish initiative and the containment of the Kurdish movement.' New Perspectives on Turkey 44, pp.103-127.

Çıdam, Çiğgdem (2010) ‘Antonio Negri’s Radical Critique of Contemporary Capitalism: Invoking Love, Revolutionizing Politics and Theorizing Democracy.' Paper presented at the Annual Meeting of Political Science Association Washington DC, September 1-4, 2010.

Ergin, Sedat (2009) ‘Politicians also subject to gravity’ (accessed 9 April 2009).

Gambetti, Zeynep (2009) 'Politics of place/space: The spatial dynamics of the Kurdish and Zapatista movements.' New Perspectives on Turkey 41, pp.43-87.

Gellner, Ernest (1983) Nations and Nationalism, Oxford: Basil Blackwell.

Gellner, Ernest (1997) ‘The Turkish Option in Comparative Perspective.' In: Sibel Bozdoğan and Reşat Kasaba (eds) Rethinking Modernity and National Identity in Turkey. Seattle and London: University of Washington Press.

Güneş, Cengiz (2012) The Kurdish National Movement in Turkey: From Protest to Resistance. London \& New York: Routledge.

Hardt, Michael and Antonio Negri (2000) Empire. Cambridge: Harvard University Press

Hardt, Michael and Antonio Negri (2004) Multitude: War and Democracy in the Age of Empire, New York: Penguin Press.

Hardt, Michael and Antonio Negri (2009) Commonwealth, Belknap Press of Harvard University Press.

Harvey, Neil (2005) 'Inclusion Through Autonomy: Zapatistas and Dissent,' NACLA Report on the Americas 39, pp.12-45.URL: http://www2.fiu.edu/ hudsonv/Harvey.pdf (accessed 12 June 2010).

Heper, M. (2007) The state and Kurds in Turkey. New York: Palgrave Macmillan.

Jongerden, Joost (2007) The Settlement Issue in Turkey and the Kurds, Leiden \& Boston: Brill.

Jongerden, Joost and Ahmet Hamdi Akkaya (2011) 'Born from the Left. The making of the PKK'. In: Marlies Casier and Joost Jongerden (eds). Nationalisms and Politics in Turkey: Political Islam, Kemalism and the Kurdish Issue. London \& New York: Routledge.

Karasu, Mustafa (2009) Radikal demokrasi. Neuss: Mezopotamya Yayınları.

Küçükaydın, Demir (2009) Öcalan'a Mektuplar, $2^{\text {nd }}$ ed., Köxüz Digital Yayınlar. URL: http:// www.akintiya-karsi.org/koxuz/node/4758 (accessed 15 January 2013).

Laclau, Ernesto and Chantal Mouffe (1985) Hegemony and socialist strategy: towards a radical democratic politics. London / New York: Verso. 
Lenin, Vladimir Ilyich (1972 [1914]) ‘The Right of Nations to Self-Determination,' in: Collected Works, Moscow: Progress Publishers, Vol.20, pp.393-454.

Newman, Saul (2010) 'The horizon of anarchy: Anarchism and contemporary radical thought', Theory and Event 13 (2).

Öcalan, Abdullah (2004) Bir halkı savunmak. Weşanên Serxwebûn.

Öcalan, Abdullah (2008) War and Peace in Kurdistan, Cologne: International Initiative Freedom for Öcalan - Peace in Kurdistan.

Özcan, Ali Kemal (2006) Turkey's Kurds: A Theoretical Analysis of the PKK and Abdullah Öcalan. Oxon: Routledge.

Özkök, Ertuğrul (2009) ‘Sanacaksınız ki karşı çıkacağım’ (accessed 9 April 2009).

PKK (2005) Partiya Karkerên Kurdistan PKK Yeniden Inşa Kongre Belgeleri. Istanbul: Çetin Yayınları.

PKK (2009) Kürt Sorununda Çözüme Doğru Demokratik Özerklik. Weşanên Serxwebûn

Yeğen, Mesut (1999) 'The Kurdish Question in Turkish State Discourse'. Journal of Contemporary History 34 (4), pp.555-568.

White, Damian F. (2008) Bookchin: A Critical Appraisal. London: Pluto Press.

Žižek, Slavoj (2007) Robespierre, Virtue and Terror. London: Verso.

\section{NOTES}

1. Özcan 2006; Akkaya and Jongerden 2011; Jongerden and Akkaya 2011; and recently, a book by Cengiz Güneş (2012), based on his PhD dissertation dealing with the ideology of the PKK on the basis of a critical analysis of Kurdish identity.

2. Newman accredited the anarchism 'as the "unacknowledged referent" in this change for current debates in radical political philosophy (Newman, 2010). In this article, Newman admitted also the radical nature of certain form of identity politics in many non-Western societies, mentioning specifically asserting a Kurdish cultural identity in Turkey, although he argued that any kind of identity politics in many Western societies is no longer necessarily radical.

3. Laclau and Mouffe discussed the shortcomings of liberal democratic theory as well as of the classical Marxist discourse in a way that "the task of the Left not to renounce liberal-democratic ideology, but on the contrary, to deepen and expand it in the direction of a radical and plural democracy' (1985: 176).

4. Furthermore, the architect of the PKK's program of radical democracy, its imprisoned leader Abdullah Öcalan, is clearly influenced by the works of Negri and Hardt, in particular Multitude (2004), and the works of Murray Bookchin.

5. Hardt and Negri distinguish three forms of representation, appropriated, free and instructed representation. Appropriated representation has the weakest link and the strongest separation between representatives and represented. The representatives are not selected, appointed or controlled but interpret the will and interest of the represented. In free representation the represented have a connection with the representatives, but their control is limited, for example by means of temporal election. The third one is instructed representation, in which the representatives are bound to the instructions of the represented.

6. By singularity, Hardt and Negri mean 'a social subject whose difference cannot be reduced to sameness, a difference that remains different' and, for them, ' the multitude is composed of a set of singularities' (2004: 99). 
7. Öcalan, Prison Notes, March 9, 2005;Hardt and Negri 2004: 249.

8. Demir Kucukaydin, Öcalan'a Mektuplar, Köxüz Digital Yayınlar, 2009, $2^{\text {nd }}$ ed.

9. The first group consists mainly of two defence texts, the main text, submitted to the court in Imrali and an annex, submitted to the Court of Appeals in Ankara in 1999 and to a local court in Urfa in 2001. These first texts were published under the names of Declaration on the Solution of the Kurdish Question, and Urfa: The Symbol of history, divinity and wretched[ness] in the basin of the TigrisEuphrates. The second group of defence texts, submitted to the ECHR in 2001, to an Athenian court in 2003 and to the Grand Chamber of the ECHR in 2004, consisted of two books which together comprised three volumes. The first book (of two volumes) was published as From Sumerian Clerical State towards People's Republic I-II (2001), while the second book (and third volume) was published as The Defence of Free Man (2003) - known in PKK circles as the 'Athens Defence' - and Defending a People (2004 ). Lastly Ocalan submitted another text of defence to the ECHR in Strasbourg concerning his case for the right of fair trial. In 2009 and 2010, this defence text which Ocalan defines as problematizing the capitalist modernity, was published in Turkish in four volumes.

10. In discussion on 'ambivalences of Modernity (2009: 83-100) Hardt and Negri point out Marx's debate on Mir, the Russian peasant community as an already existing basis for communism, and similarly arguments by Jose Carlos Mariategui who discussed the role of Andean indigenous communities, the ayllus, as the basis for commonwealth and resistance.

11. Nilüfer Zengin, 'DTP Congress: “Democratic Autonomy”,' Bianet, 31 October 2007. URL: http://www.bianet.org/english/local-goverment/102622-dtp-congress-democratic-autonomy (accessed 15 January 2013).

12. 'Demirbaş: Çok Dilli Belediyecilik Anayasa'ya uygun,'FiratNews, 9 April 2007. URL: http:// www.firatnews.com/index.php?rupel=arsiv\&anf=nuce\&nuceID=23190 (accessed 15 January 2013). 13. Tolga Korkut, 'State Wants Kurdish-Speaking Employees, but Tries Kurdish Mayor,' Bianet, 25 May 2009. URL: http://www.bianet.org/english/minorities/114727-state-wants-kurdishspeaking-employees-but-tries-kurdish-mayor (accessed 15 January 2013); Erol Önderoğlu, 'Multilingual Diyarbakir Municipality on Trial,' Bianet, 9 November 2007. URL: http:// www.bianet.org/english/minorities/102799-multilingual-diyarbakir-municipality-on-trial.

14. In December 2009, the Constitutional Court ruled for the closure of pro-Kurdish DTP (Democratic Society Party) as it had done for the previous pro-Kurdish parties, and imposed a political ban on 37 of its members, including its Co-chairs Ahmet Türk and Aysel Tuğlukwho were deposed from their duties as MPs. However the legal Kurdish politics proceeded on its way, almost undisturbed, through a new party, named Barış ve Demokrasi Partisi (BDP, the Peace and Democracy Party). The DTP election success was underscored in similar fashion by the BDP in national votes during 2011, which won 36 deputies.

15. In South Africa, there was a tradition of the organization in the form of the congress. ANC (African National Congress), the South African Indian Congress, the Coloured People's Congress and the Congress of Democrats formed the Congress of the People in 1955. This was a congress of all the people of South Africa and it adopted a document, named the Freedom Charter in which they presented their demands for the kind of South Africa they wanted.

16. 'Kürt Sorununda Çözüme Doğru Demokratik Özerklik',Weşanên Serxwebûn 146 (2009), p.95.

17. Afterwards, the DTK became a very prominent actor in Kurdish politics. Now it is a openly organized congress having a council of 101 members, elected by 850 delegates, of which 300 members are elected party members such as the members of parliament, mayors etc., 500 elected delegates and 50 reserved for minorities and particular groups such as academicians.

18. 'DTK “Uluslararası Çözüm Konferansı” düzenliyor,' FiratNews.com, 2 January 2010. URL: www.firatnews.com/index.php?rupel=nuce\&nuceID=20003 (accessed 15 January 2013).

19. 'Müzakere Konferansı'nın sonuç bildirgesi açıklandı,' FiratNews.com, 28 February 2010. URL: http://www.firatnews.com/index.php?rupel=nuce\&nuceID=22423 (accessed 15 January 2013). 
20. 'DTP'nin Yerel Yönetimler Modeli Netleşiyor,' Haftaya Bakış, 2-9 February 2008. URL: http:// www.ekolojistler.org/dtpnin-yerel-yonetimler-modeli-netlesiyor.html (accessed 15 January 2013).

21. “'Anadilde Eğitim” için 1 milyon izma Meclis'te,' 25 February 2011. URL: http:// www.bianet.org/bianet/ifade-ozgurlugu/128164-anadilde-egitim-icin-1-milyon-imza-mecliste (accessed 15 January 2013).

22. Zeynep Gambetti, 'Alternatif bir sol proje: demokratik özerklik,'Birgün, 26 December 2010. URL: http://www.birgun.net/politics_index.php? news_code $=1293360839 \&$ year $=2010 \&$ month $=12 \&$ day $=26$ (accessed 15 January 2013).

23. 'Mezopotamya sosyal forumu için çağrl,' URL: http://www.msf.web.tr/msf/en/who-arewe.html (accessed 15 January 2013); see also Casier 2011.

24. Erhan Üstündağ, 'Possible Solution for Kurdish Question suits EU Accession Process,' Bianet, 1 July 2010. URL: http://www.bianet.org/english/english/123087-possible-solution-for-kurdishquestion-suits-eu-accession-process(accessed 15 January 2013).

25. Inclusion and autonomy do not contradict with each other as a lengthy quotation from a geographically, culturally and politically faraway context gives some insights: 'At first glance, these twin demands for inclusion and autonomy seem to contradict each other. However, the contradiction only arises if it is assumed that the two are mutually exclusive, a form of reasoning that continues to block the full recognition of indigenous rights in Chiapas and around the world. Until the 1980s, the political importance of cultural diversity tended to be subordinated to other concerns related to matters of state formation and economic development. In Mexico and other Latin American countries, inclusion assumed adherence to a single national identity that was decidedly non-indigenous. However, the long-term viability of indigenous autonomy may depend more on its appropriation at the local level rather than on the revision of legal statutes. In this regard, autonomy is best thought of as a marker of political identity rather than a legal concept' (Harvey 2005: 16).

\section{ABSTRACTS}

One of the most important secular political movements in the Middle East, the Kurdistan Workers Party (PKK) underwent a profound transformation in the 2000s. What the PKK has experienced in this period was a comprehensive restructuration of its organization, ideology and political-military struggle, changing its course towards a project of radical democracy. In this article we explore the content of this new project, and its practical implications. Through this discussion, our study addresses a gap in Turkish and Kurdish studies. Only few studies deal explicitly with the political ideology of the PKK. The data for this article has been collected through a study of Öcalan's defence texts and his 'prison notes', along with key PKK documents, such as congress reports, formal decisions and the writings of its cadre, such as Mustafa Karasu. We conclude that the project for radical democracy is based on the conception of 'politics beyond the state, political organisation beyond the party, and political subjectivity beyond class' and can have the opportunity to change the centralist tradition in Turkish political system as well as the statist and class reductionist political thought in the Left in Turkey. 
INDEX

Keywords: democratic autonomy, democratic confederalism, democratic Republic, Kurdistan, PKK, radical democracy 